\title{
The Combined QBO and ENSO Influence on Tropical Cyclone Activity over the North Atlantic Ocean
}

\author{
Alejandro Jaramillo (D), Christian Dominguez*(D), Graciela Raga (D) and Arturo I. Quintanar (D) \\ Instituto de Ciencias de la Atmósfera y Cambio Climático, Universidad Nacional Autónoma de México, \\ Mexico City 04510, Mexico; ajaramillo@atmosfera.unam.mx (A.J.); raga@unam.mx (G.R.); \\ arturo.quintanar@atmosfera.unam.mx (A.I.Q.) \\ * Correspondence: dosach@atmosfera.unam.mx
}

Citation: Jaramillo, A.; Dominguez, C.; Raga, G.; Quintanar, A.I. The Combined QBO and ENSO Influence on Tropical Cyclone Activity over the North Atlantic Ocean. Atmosphere 2021, 12, 1588. https://doi.org/ $10.3390 /$ atmos 12121588

Academic Editors: Wei Zhang, Kevin A. Reed, Kimberly Wood and Maofeng Li

Received: 31 October 2021

Accepted: 25 November 2021

Published: 29 November 2021

Publisher's Note: MDPI stays neutral with regard to jurisdictional claims in published maps and institutional affiliations.

Copyright: (c) 2021 by the authors. Licensee MDPI, Basel, Switzerland. This article is an open access article distributed under the terms and conditions of the Creative Commons Attribution (CC BY) license (https:// creativecommons.org/licenses/by/ $4.0 /)$.
Abstract: The Quasi-Biennal Oscillation (QBO) and the El Niño-Southern Oscillation (ENSO) largely modulate the zonal wind in the tropics. Previous studies showed that QBO phases produce changes in deep convection through an increase/decrease in the tropopause height over the tropics and subtropics. This study investigates the combined effects of QBO and ENSO on tropical cyclone activity by modulating tropopause height. We found that tropopause height increases over the Gulf of Mexico, the Caribbean region, and the Western North Atlantic Ocean during La Niña + QBOW, allowing deeper tropical convection to develop over those regions. As a consequence, TC activity over those regions is not only increased in number but also enhanced in intensity. Conversely, during El Niño + QBOE, most deep tropical convection is inhibited over those same regions due to the decrease in tropopause height over the subtropics. We conclude that QBO effects on TCs and deep convection should be studied in combination with ENSO. Additional comparative studies using long record data at high vertical resolution are needed to fully understand to what extent QBO interacts with ENSO in the lower tropical stratosphere and upper tropical troposphere.

Keywords: QBO; ENSO; tropical cyclones; tropopause height; deep convection

\section{Introduction}

The Quasi-Biennial Oscillation (QBO) is a stratospheric oscillation of downward propagating wind regimes classified into the westerly phase (QBOW) and the easterly phase (QBOE), each phase lasting 28 months on average [1]. Typically, the tropical winds located in the $10^{\circ} \mathrm{S}-10^{\circ} \mathrm{N}$ region at $30 \mathrm{hPa}$ or $10 \mathrm{hPa}$ are used to create the QBO index, employing reanalysis or radiosonde data $[2,3]$. Observational and model evidence suggest that the lower tropical stratosphere communicates with the upper tropical troposphere by exchanging mass, energy, and momentum [4]. However, understanding connections between the lower stratosphere and upper extratropical troposphere is more complex [5]. Some studies have advanced on analyzing the interactions of QBO with tropical oscillations, mainly in winter (e.g., Madden-Julian Oscillation (MJO) [6] and El Niño-Southern Oscillation (ENSO) [7]), showing potential applications from sub-seasonal to seasonal forecasts. For example, Taguchi (2010) found that the variations of QBO were stronger during El Niño events. Thus, the QBO phases can indirectly perturb the extratropical response to El Niño at different magnitudes during boreal winter by altering Rossby wave trains. This teleconnection reveals a potential source of predictability for El Niño events over the Central and Northwestern Pacific region [8].

Studies on QBO interactions with ENSO go back to the 1980s. William Gray was a pioneer in studying QBO and proposing several physical mechanisms. While QBOE was hypothesized to be favorable for initiating El Niño events, QBOW could provide beneficial atmospheric conditions for the onset of La Niña events [9]. In addition, Gray et al. (1992) suggest that the QBO signal can communicate with ENSO phases through variations in 
vertical wind shear, and consequently, these interactions modulate the sea surface temperatures over the tropical Pacific Ocean [9]. Specifically, this study introduced the concept of meridionally varying on-off equator differences in deep convection, highlighting the influence of QBO and ENSO on convection at different latitudes. Following Gray's studies, Collimore et al. (2003) showed that QBO influences the vertical extent of convection in the tropics and subtropics through fluctuations in the tropopause height [10]. They propose that $\mathrm{QBO}$ phases induce changes in the vertical cross-tropopause shear, which impacts the occurrence of deep convection in tropics and subtropics differently. QBOW (QBOE) implies mass convergence (divergence) in the lower stratosphere, causing subsidence and warming (ascending and cooling) in the tropical lower stratosphere. However, the subtropical lower stratosphere simultaneously experiences ascent (descent), so the tropopause is higher (lower) and cooler (hotter) than normal. The latter implies that QBOW (QBOE) decreases (increases) the tropopause height and inhibits (enhances) deep convection in the equator. However, the opposite occurs for the subtropics [10].

Recently, Hitchman et al. (2021) defined this QBO-induced circulation as the Mean Meridional Circulation (MMC) between the tropics and subtropics. Moreover, their study demonstrates that $\mathrm{QBO}$ modulates tropopause temperatures linked to deep tropical convection over the Atlantic and Indian Oceans, mainly in June-July-August [11]. In addition, they show that QBO influences the Walker circulation, which is reduced during MarchApril-May under QBOW conditions, and the Hadley cell [11].

In terms of TCs, Gray was also the first to show that the QBO was a useful predictor for the TC activity over the North Atlantic Ocean (NA) and even for forecasting the probabilities of TC landfalling over the US and Caribbean islands [12,13]. Gray (1984) found that QBOW produced more TCs over NA when compared to the QBOE during the 1949-1983 period [12]. However, this QBO-TC relationship ceased in the mid-1990s [14]. Fink et al. (2010) suggested that this change could probably be attributed to the shift to AMO+ during this decade [15]. Moreover, Camargo and Sobel (2010) explored in detail the possible physical mechanisms that made the QBO influence on TC activity over NA disappear (e.g., volcanic activity, solar forcing, decadal variability of $\mathrm{QBO}$, and outflow temperature) [16]. It is worth mentioning that this study excluded ENSO signal from the analysis, and no significant influence of QBO on TCs over NA was found. Therefore, they suggest the use of longer datasets to provide a more robust physical explanation.

Camargo et al. (2007) showed that several variables are modulated by ENSO, namely the mid-tropospheric humidity at $600 \mathrm{hPa}$, absolute vorticity at $850 \mathrm{hPa}$, tropospheric vertical wind shear between $850 \mathrm{hPa}$ and $250 \mathrm{hPa}$, and potential TC intensity over NA. On the other hand, mid-tropospheric humidity and tropospheric wind shear appear to be the most critical variables for developing TCs. Under El Niño (La Niña) conditions, tropospheric vertical wind shear intensifies (decreases) over NA, so fewer (more) TCs are expected mainly in the Main Development Region, the Caribbean region, and Gulf of Mexico [17]. In other words, even when the sea surface temperatures (SSTs) are high $\left(>26^{\circ} \mathrm{C}\right)$, the tropospheric vertical wind shear plays a leading role in determining to what extent the TC activity is active [18]. The QBO can modulate the TC trajectory over the western North Pacific Ocean, with more TCs moving near the East China Sea under QBOW conditions and more TCs closer to the eastern shore of Japan under QBOE conditions [19]. More recently, off-equator and centered-equator winds in the lower stratosphere and upper troposphere were analyzed to dynamically explain TC variability over this basin [20]. These results revealed that $\mathrm{QBO}$ modulation is not restricted to the equator, and that in fact, $\mathrm{QBO}$ can also influence upper-tropospheric winds $(200 \mathrm{hPa})$ from July to October.

To date, the physical coupling mechanisms between ENSO and QBO have not been well understood. This lack of understanding is probably linked to the small number of lower-stratospheric observations worldwide. Some questions remain unanswered over the NA from the studies discussed. For example, most studies isolate QBO modulation from the ENSO signal, but their interactions and combined influence on TCs have not been analyzed yet. Furthermore, analyzing longer datasets would allow exploring these 
different phase combinations: El Niño + QBOW, El Niño + QBOE, Neutral + QBOW, Neutral + QBOE, La Niña + QBOW, and La Niña + QBOE. These combinations could lead to differences in large-scale environments that change TC behavior over NA. The latter can be explained by diverse physical induced mechanisms or constructive and destructive interference between these two oscillations. In this sense, our study focuses on providing a relationship between QBO and ENSO, but we do not aim at exploring the physical coupling between a QBO and ENSO. To answer the physical reasons for coupling requires the use of global stratospheric observations and global circulation models.

The main objective here is to analyze QBO-ENSO phase combinations to determine their impact on TC activity over NA. The outcome of this study could be key in understanding variations in TC activity under the same ENSO phase. For example, the TC activity in 2010 (19 TCs) was not as active as that in 2020 (30 TCs), even though both seasons were La Niña events. Differences in TC occurrence under the same ENSO phase are relevant since they may affect landfalling TC frequency, and consequently, the TC associated variation in extreme precipitation in certain regions [21] and resulting socioeconomic impacts [22]. Therefore, $\mathrm{QBO}$ could be a potential contributor to understanding TC current variability over NA. We use the NCEP-NCAR reanalysis during the 1953-2020 period [23] and the QBO dataset from the University of Berlin [2] to analyze these combinations.

The next section describes the reanalysis, observational data, and the dataset of TC tracks over NA. Section 3 analyzes the QBO-ENSO influence on TC activity and provides a dynamical explanation for such differences. Finally, the summary and conclusions are given in Section 4.

\section{Materials and Methods}

\subsection{ENSO and QBO}

We used the monthly mean zonal wind at $30 \mathrm{hPa}$ of the $\mathrm{QBO}$ dataset from the University of Berlin [2]. Multiple pressure levels of monthly zonal wind from 1953 to the present can be found at http:/ /www.geo.fu-berlin.de/en/met/ag/strat/produkte/qbo/ index.html (accessed on 25 November 2021). These data were obtained from a combination of observations in a few equatorial radiosonde stations. Although there are longitudinal variations of the QBO, the asymmetries in the prevailing wind are fairly small in the lower stratosphere $[23,24]$. Therefore, zonal winds at $30 \mathrm{hPa}$ measured at particular tropical locations might represent the equatorial belt [2]. We chose the $30 \mathrm{hPa}$ mean zonal winds since Camargo and Sobel (2010) found significant relationships between the QBO and TCs only at this level [16]. First, we constructed a QBO Index (QBOI) by standardizing the monthly $30 \mathrm{hPa}$ zonal winds. Next, we used the climatological mean and standard deviation to obtain these standardized anomalies considering all months from the 1953-2020 period. Then, we averaged the monthly standardized anomalies from June to November. Monthly standardized anomalies whose QBOI $\geq 0$ are considered QBOW phase, and monthly standardized anomalies whose $\mathrm{QBOI}<0$ are considered part of the QBOE phase. In this way, we used this average to determine annual values for the QBO phases during the 1953-2020 period. This method adequately represents westerly winds for the QBOW and easterly winds for the QBOE phase during the months when tropical convection occurs.

For ENSO, we used the Oceanic Niño Index (ONI) (obtained from https:/ / origin. cpc.ncep.noaa.gov/products/analysis_monitoring/ensostuff/ONI_v5.php, accessed on 25 November 2021). This index is defined as the 3-month running mean (3-MRM) of anomalies in SSTs in the Niño $3-4$ region $\left(5^{\circ} \mathrm{S}-5^{\circ} \mathrm{N}, 120^{\circ} \mathrm{W}-170^{\circ} \mathrm{W}\right)$ [24]. An ENSO event is determined when the averaged SST anomalies from June to November are $\geq 0.5^{\circ} \mathrm{C}$ for El Niño, and the averaged SST anomalies are $\leq-0.5^{\circ} \mathrm{C}$ for La Niña. Years whose SST anomalies vary from $-0.5^{\circ} \mathrm{C}$ to $0.5^{\circ} \mathrm{C}$ are considered neutral years [25].

To classify each year as a combination of ENSO with QBO, we determined annually when both indexes adjust to the QBO phase and ENSO phase definitions considering the JJASON season during the 1953-2020 period. Figure 1 shows the time series of the 
QBOI and ONI mean values for JJASON per year. The complete list of years with their corresponding annual mean values for ONI and QBO is shown in Table S1.
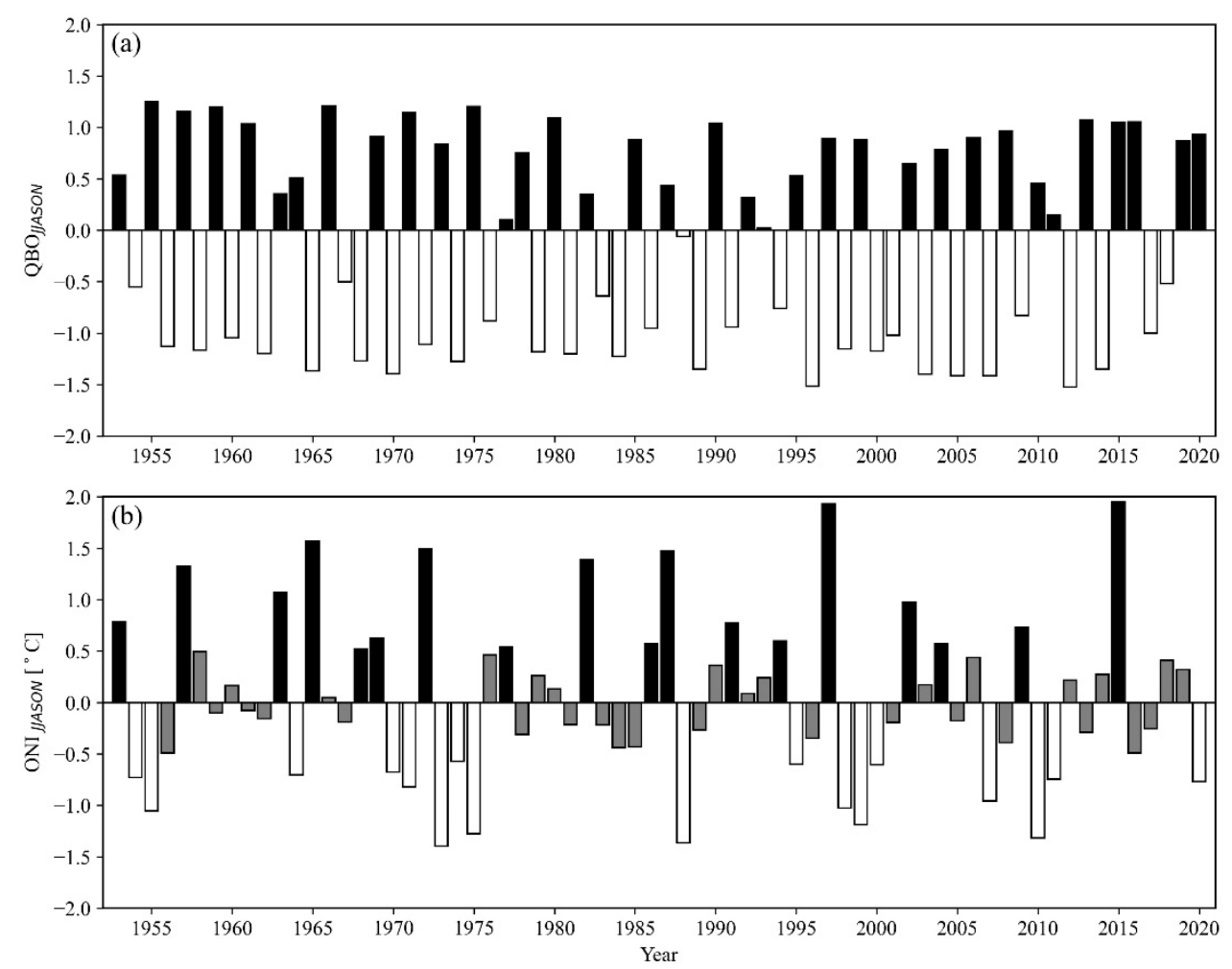

Figure 1. Time series of the mean values of QBOI (a) and ONI (b) for the season JJASON per year. For the QBO time series, black and white bars represent the $\mathrm{W}$ and $\mathrm{E}$ phases, respectively. For the ONI time series, black, grey, and white represent El Niño, Neutral, and La Niña phases.

\subsection{Tropical Cyclone Number and ACE Density}

TC tracks for the period 1953-2020 in the NA were obtained from HURDAT2. This database contains TCs over the North Atlantic and Eastern North Pacific Oceans from 1851 and 1949, respectively [26]. TC location and frequency have been considered more accurate since 1970 due to satellite observations in this dataset [27]. In general, HURDAT2 is reliable after the aircraft reconnaissance era (after 1948), but some storms can still be missed, and their intensities can be low during the pre-satellite era (1948-1969), especially weak TCs whose lifetime is up to 2 days [28]. However, we used the TC tracks for the 1953-2020 period according to the availability of QBO data.

TC number density is computed as the sum of the number of TC track points per grid of $2.5^{\circ} \times 2.5^{\circ}$ during the season JJASON for a given year divided by the area in $\mathrm{km}^{2}$. The TC density for each ENSO+QBO phase is an average of the TC densities during the years where both ENSO and QBO phases were active. For example, the TC tracks that occurred in 1953, 1957, 1963, 1969, 1977, 1982, 1987, 1997, 2002, 2004, and 2015 are considered for defining TC density under El Niño + QBOW conditions (See Table S1). The TC density anomalies are defined by subtracting the TC density mean under ENSO+QBO conditions from the climatological TC density of the whole period (1953-2020).

To analyze TC intensity, we computed the Accumulated Cyclone Energy (ACE) density, which is calculated similarly to the TC density. The ACE density is defined as the sum of the ACE located at each grid of $2.5^{\circ} \times 2.5^{\circ}$ during JJASON for a given year divided by the area in $\mathrm{km}^{2}$. This gridded ACE represents all the TC track points situated at each grid of $2.5^{\circ} \times 2.5^{\circ}$. ACE per each TC track point is computed as follows:

$$
\mathrm{ACE}=1 \times 10^{-4} \sum_{\mathrm{i}} \text { Speed }_{\mathrm{i}}^{2}
$$


where Speed $_{i}$ is the TC maximum sustained velocity (in knots) estimated every six-hour interval, as extracted from the HURDAT database. ACE is a measure that integrates physics and statistics to determine the degree of TC activity [29]. Similarly to the TC density, the anomalies of ACE density are obtained by subtracting the mean ACE density under $\mathrm{ENSO}+\mathrm{QBO}$ combinations from the climatological ACE density of the whole period.

\subsection{NCEP-NCAR Reanalysis}

We used tropopause pressure (in $\mathrm{hPa}$ ) and meridional wind at $150 \mathrm{hPa}$ and $70 \mathrm{hPa}$ (in $\mathrm{m} / \mathrm{s}$ ) and the zonal and meridional wind at $850 \mathrm{hPa}$ and $200 \mathrm{hPa}$ for the study region, defined as a domain from $100^{\circ} \mathrm{W}$ to $10^{\circ} \mathrm{W}$ and from $5^{\circ} \mathrm{N}$ to $35^{\circ} \mathrm{N}$ (see Figure 2). Additionally, we used the SSTs, vertical velocity (omega) from $1000 \mathrm{hPa}$ to $100 \mathrm{hPa}$ during the study period. No stratospheric levels are available for omega. All these variables were obtained from the National Centers for Environmental Prediction-National Center for Atmospheric Research (NCEP-NCAR) reanalysis [23].

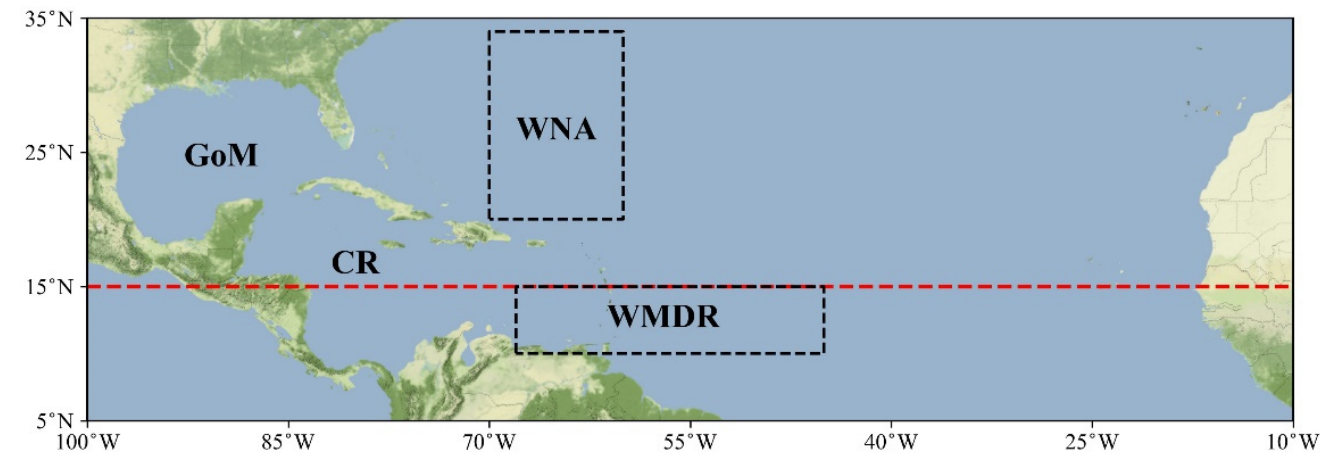

Figure 2. The domain of the North Atlantic Ocean considered for this study and four study regions: Gulf of Mexico (GoM), Caribbean region (CR), Western North Atlantic (WNA), and Western Main Development region (WMDR). The red line at $15^{\circ} \mathrm{N}$ shows the geographical division between the Tropics from Subtropics used for this work.

In addition, we assumed that a standard atmosphere could be used to estimate tropopause height (TH) (in meters) from the tropopause pressure. Although no satellitebased observations were available before 1978 for data assimilation in the NCEP-NCAR reanalysis [30], the tropical tropopause during the 1979-1997 period was analyzed in previous studies, and it was found that NCEP tropopause height adequately captures data from 26 radiosonde stations, even when NCEP-NCAR tropopause is simulated warmer by $3-5 \mathrm{~K}$ and higher in pressure by $2-6 \mathrm{hPa}$ [31]. Randel et al. (2000) concluded that reanalysis has biases in tropopause height and temperature, but it can capture seasonal and interannual variations, as QBO and ENSO, reasonably for the 1979-1997 period [31].

More recently, Hitchman et al. (2021) analyzed the statistical significance of changes in NCEP tropopause temperature and 70-150 hPa zonal wind shear under the QBO phases for June-July-August during the 1958-1978 and 1979-2000 periods. They found that the NCEP tropopause temperature and zonal wind shear slightly change between both periods, and changes are highly statistically significant for the tropics during the two periods [11]. Thus, we have confidence in the presence of multidecadal variability in TH over the 1953-2020 period. To remove this multidecadal variability from the reanalysis data (except for SSTs), linear trends were removed in time using the least-squares fit technique. Thus, all variability associated with periods larger than ten years were removed by filtering the Fourier coefficients associated with those periods. Thereafter, we create all the anomalies, except for SSTs, using filtered data. Additionally, the standard error of the mean was calculated as the ratio of the standard deviation to the square root of the sample size.

To study the anomalous meridional circulations associated with QBO proposed by Collimore et al. (2003) [10], we calculated mean values of meridional wind at $150 \mathrm{hPa}$ and $70 \mathrm{hPa}$ (cross tropopause levels). We defined the difference between the meridional 
wind at those levels (V70-V850) and analyzed the anomalies during the ENSO-QBO phase combinations. Similarly to this definition, the difference between the meridional wind at $850 \mathrm{hPa}$ and $200 \mathrm{hPa}$ was used to diagnose the Hadley Cell's zonally averaged structure [32]. Thus, this difference is a tool for analyzing the zonally averaged circulations since other methods, like the mass stream function, neglect the regional dependency on the tropical atmospheric circulation [32]. Following Sun et al. (2019), positive (negative) values of V70-V850 indicate clockwise (anticlockwise) circulation in the Northern Hemisphere [32].

\section{Results and Discussion}

TC density anomalies for each ENSO-QBO combination are shown in Figure 3. TC densities under El Niño and La Niña conditions are opposite. These results are consistent with previous studies, as expected [17,22]. Additionally, TC densities under QBOW and QBOE phases reveal diverse patterns. The QBO phases make TC density different under the same ENSO phase, especially over the Western NA (WNA), the Caribbean region $(\mathrm{CR})$, and the Gulf of Mexico (GoM). For example, under La Niña + QBOW conditions (Figure 3e), TC density is the highest compared to the other ENSO-QBO combinations, while El Niño + QBOE (Figure 3b) is the least active. The latter results are supported by Gray (1984) and Gray et al. (1992). They found that TC season is above-normal or slightly above-normal when winds at $30 \mathrm{hPa}$ are westerly (i.e., QBOW), combined with Non-El Niño years over NA. The proposed physical mechanism to explain these changes in TC activity under QBO and ENSO phases only focuses on the vertical wind shear. While QBOE produces a conducive environment for TC formation at $\sim 8^{\circ} \mathrm{N}-15^{\circ} \mathrm{N}$ and suppression of TC development over the subtropics, QBOW induces a less favorable environment for TC formation at $\sim 8^{\circ} \mathrm{N}-15^{\circ} \mathrm{N}$ and enhancement of TC development off $-15^{\circ} \mathrm{N}$. This relationship is reinforced during El Niño + QBOE and La Niña + QBOW, when the signal is amplified $[9,12]$. We will discuss later why TH fluctuations are also important but hitherto overlooked in previous studies. Under Neutral-QBO conditions, slight variations can be seen over the Western Main Development Region (WMDR) and CR (Figure 3c,d). These regions are more active during Neutral $+\mathrm{QBOE}$ (Figure 3d). However, the mid-Atlantic Ocean is more active during Neutral + QBOW (Figure 3c). It is interesting to see that Neutral-QBO conditions clearly show the expected QBO influence on TC activity for the strip of $7.5^{\circ} \mathrm{N}-15^{\circ} \mathrm{N}$.

We test the statistical significance for each QBO-ENSO phase combination. The crosses indicate the regions where the $p$-value of the Mann-Whitney $\mathrm{U}$ test is lower than 0.1 (i.e., significance is higher than $90 \%$ ). Similar results were obtained using the two-sided T-test (Figure S1). The El Niño and La Niña phases seem to be more active during the QBOW phase (Figure 3a,e), while the Neutral phase seems to be more active during the QBOE phase (Figure 3d). This result becomes evident when we estimate the mean TC density anomalies in the whole domain of NA (Figure S2). The differences in the TC density anomalies among the ENSO-QBO phase combinations are highly related to the TC activity over WNA. In other words, statistically significant differences in TC density can be seen over WNA during La Niña + QBOW and La Niña + QBOE, but they vanish during El Niño + QBOW and El Niño + QBOE. Only under neutral conditions, a clear signal can be seen during QBOW and QBOE over WMDR, as mentioned by previous studies [12,14]. The boxes shown in Figure $3 c-f$ represent the tropics (WMDR) and the subtropics (WMDR) where statistical significance can be found. 

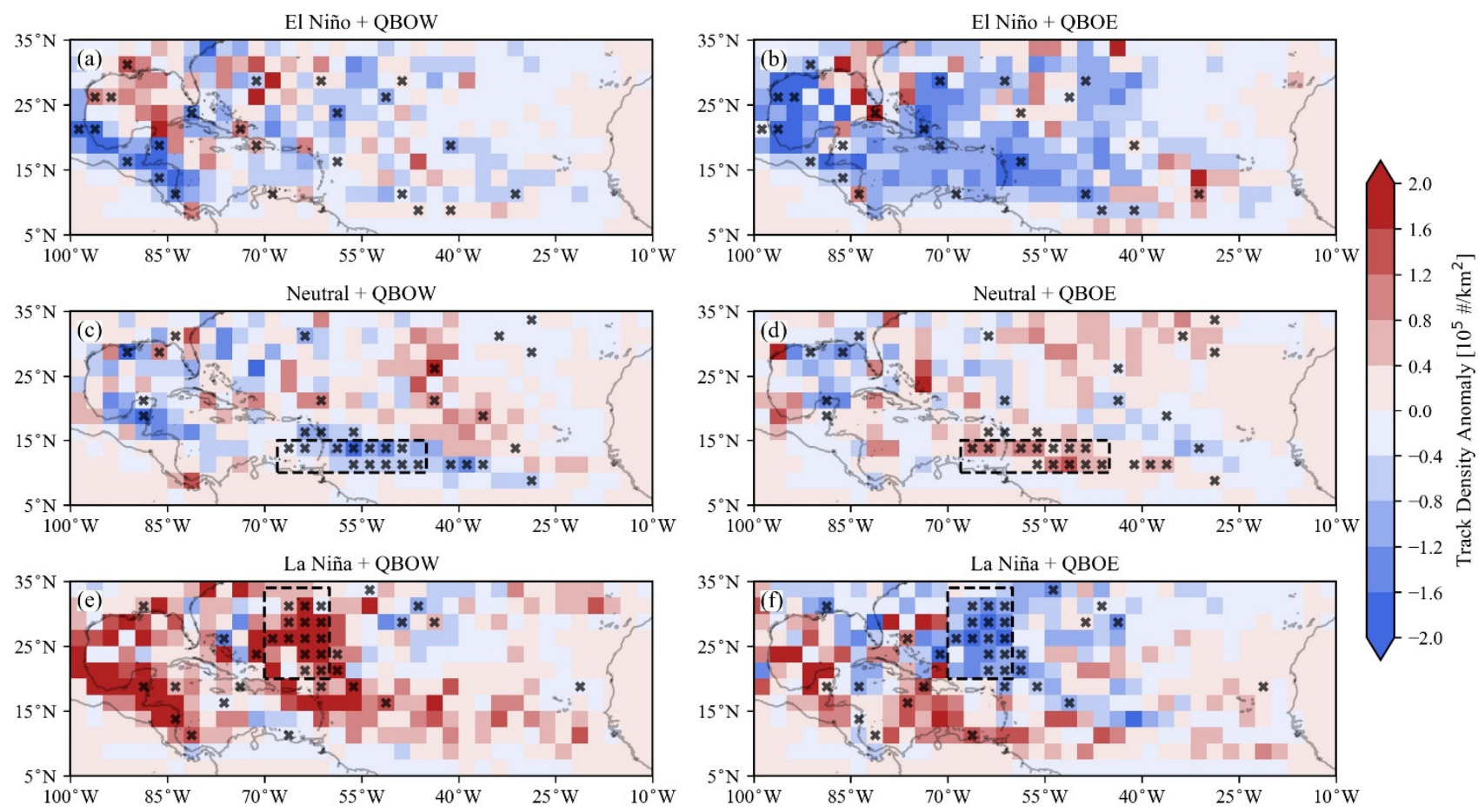

Figure 3. Mean TCs track density anomalies during the season JJASON for the years classified as ENSO and QBO phases: (a) El Niño-QBOW, (b) El Niño-QBOE, (c) Neutral-QBOW, (d) Neutral-QBOE, (e) La Niña-QBOW, and (f) La Niña-QBOE during the 1953-2020 period. The crosses show the statistically significant regions where the $p$-value of the Mann-Whitney $\mathrm{U}$ test is lower than 0.1 .

ACE density anomalies for each ENSO-QBO phase combination are shown in Figure 4. The crosses show the regions where the $p$-value of the Mann-Whitney $\mathrm{U}$ test is lower than 0.1. Similar results were obtained with a two-sided T-test (Figure S3). Remarkably, the statistically significant regions are similar to those in Figure 3.

Similarly to Figure 3, the ACE density anomalies show a clear difference between ENSO and QBO phases, with QBOW being more active. El Niño + QBOE and La Niña + QBOW (Figure $4 \mathrm{~b}, \mathrm{e}$ ) show an inverse signal in the ACE density over the WNA. Remarkably, La Niña + QBOW conditions have large positive anomalies in ACE density over the WNA and the GoM (Figure 4e), while El Niño + QBOE (Figure 4b) and La Niña + QBOE (Figure 4f) are less intense over the same regions. These results point out variations not only in the TC number but also in TC intensity (Figures 3 and 4), suggesting that the QBOW phase modulates favorable large-scale conditions for deep tropical convection over the subtropics $\left(15^{\circ} \mathrm{N}-35^{\circ} \mathrm{N}\right)$. This suggestion (QBO influence on deep convection) was proven in [10]. Their evidence shows that the tropopause reaches lower altitudes in the cross-equatorial region, which inhibits deep convection from developing over $10^{\circ} \mathrm{N}-10^{\circ} \mathrm{S}$ during the QBOW. However, TH is higher in the subtropics, allowing deep convection to develop from $\sim 15^{\circ} \mathrm{N}$ northwards. The opposite occurs during QBOE. Their study demonstrated that QBO influences deep convection by modulating TH fluctuations [10]. These authors also mention the cross-tropopause zonal wind shear as a secondary mechanism for explaining the development of deep convection [10]. More recently, Liess and Geller (2012) found that QBO phases can influence the Hadley Circulation activity (e.g., weakening of downwelling branch), which is partially related to the physical mechanism proposed by Collimore et al. (2003) at upper tropospheric levels [33]. However, Liess and Geller (2012) only show statistically significant evidence for the whole Pacific Ocean [33]. It is important to mention that Liess and Geller (2012) does not provide a physical mechanism for explaining an ENSO-QBO coupling [33]. 

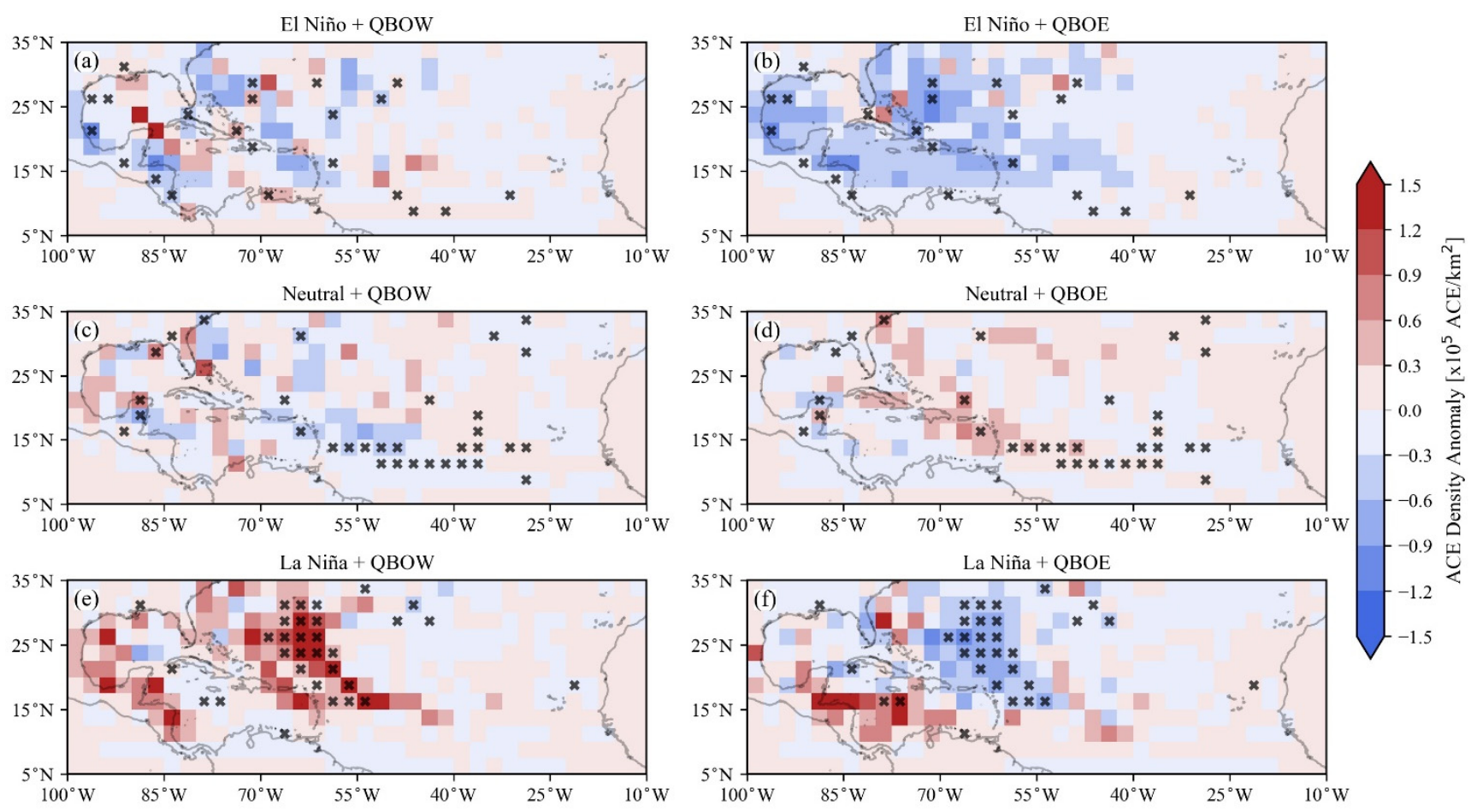

Figure 4. (a) El Niño + QBOW, (b) El Niño + QBOE, (c) Neutral + QBOW, (d) Neutral + QBOE, (e) La Niña + QBOW, and (f) La Niña + QBOE. Same as Figure 3, but for the Mean ACE density anomalies during the season JJASON for the years classified as ENSO and QBO phases during the 1953-2020 period. The crosses show the statistically significant regions where the $p$-value of the Mann-Whitney $\mathrm{U}$ test is lower than 0.1 .

The mean SSTs show no differences among ENSO-QBO phases (Figure S4). However, different behavior in standardized tropospheric vertical wind shear anomalies is notable over the whole domain of NA, mainly over GoM, CR, WNA, and WMDR. One could expect that an unfavorable (favorable) environment for TC development is associated with high (low) tropospheric vertical wind shear. Under El Niño + QBOW conditions, the tropospheric vertical wind shear increases slightly over the whole domain, and it is partially related to the TC and ACE density results for this ENSO-QBO combination (Figures $3 \mathrm{a}$ and $4 \mathrm{a}$ ). On the other hand, under El Niño + QBOE conditions, it only augments for the Tropics, but it decreases over the subtropics. Therefore, the negative anomalies in TC and ACE density only agree with the vertical wind shear over the tropics (Figures $3 \mathrm{~b}$ and $4 \mathrm{~b}$ ). Under Neutral conditions, tropospheric wind shear slightly increases (decreases) for the QBOE (QBOW) mainly over GoM and $\mathrm{CR}$, which does not fully explain the differences in TC and ACE density anomalies over those regions during QBO phases (Figures $3 c$,d and $4 c, d$ ). Finally, under La Niña conditions, standardized tropospheric wind shear anomalies are opposite during QBOE and QBOW over GoM, WNA, and a part of WMDR (Figures 3e,f and 4e,f). These results are shown in Figure S4 and reveal that tropospheric vertical wind shear partially explains the TC behavior over NA while analyzing ENSO in conjunction with QBO.

A higher tropopause allows deeper convection according to the physical mechanisms proposed by Collimore et al. (2003) [9]. QBO can modulate the TH through anomalous meridional circulations $[10,34,35]$. QBOW causes a lower tropopause in the equator while inducing higher TH in the subtropics. A reverse scenario is expected during the QBOE phase [10]. It is important to note the presence of multidecadal variability in TH (Figure S5a). Negative anomalies in TH prevailed before 1995, and positive anomalies have prevailed since that year, as previously mentioned in Section 2. To remove the possible effects of this multidecadal variability in our analysis, we remove it from the reanalysis data. Figure S5b shows the time series of $\mathrm{TH}$ after applying the filtering. 
Mean zonal TH anomalies for the study domain under ENSO phases are shown in Figure 5a, and TH anomalies under the QBO phases are shown in Figure $5 b$, where the shaded band for each phase shows the estimated standard error of the mean. While La Niña is associated with positive TH anomaly for latitudes $>20^{\circ} \mathrm{N}$, El Niño induces negative TH anomalies for latitudes $>15^{\circ} \mathrm{N}$. Similarly, positive TH anomalies occur under QBOW for latitudes $>20^{\circ} \mathrm{N}$, while negative $\mathrm{TH}$ anomalies occur under QBOE for the same latitudes. These differences suggest that the ENSO-QBO phase combination could cause constructive or destructive interference on the TH anomalies, i.e., when both ENSO and QBO phases are associated with the same (different) sign in TH anomalies, the effects on TH anomalies are strengthened (weakened). The spatial distribution of these $\mathrm{TH}$ anomalies for the whole study domain depending on the ENSO and QBO phase is shown in Figures S6 and S7 in the Supplemental Material.
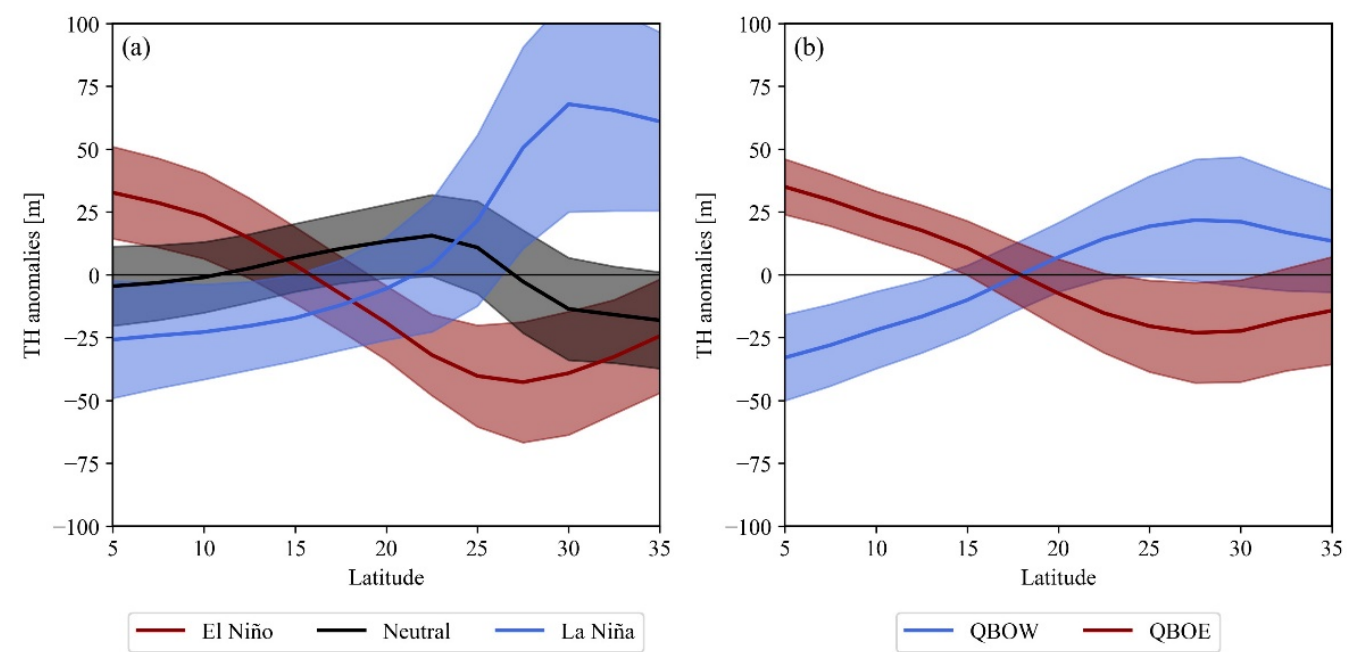

Figure 5. Mean tropopause height anomalies during the season JJASON for the years classified as (a) ENSO, and (b) QBO phases for the whole study domain during the 1953-2020 period. The shaded band for each phase shows the estimated standard error of the mean.

Figure 6 shows the spatial distribution of TH anomalies under the ENSO-QBO phase combination. Similarly to Figures 3 and 4, the crosses show the regions where the $p$-value of the Mann-Whitney $\mathrm{U}$ test is lower than 0.1 , and similar results are obtained using a two-sided T-test (Figure S8). While negative TH anomalies occur under El Niño + QBOE (Figure 6b), positive $\mathrm{TH}$ anomalies for latitudes $>15^{\circ} \mathrm{N}$ occur under La Niña + QBOW conditions, mainly over GoM and WNA (Figure 6e). These results are spatially consistent with TC and ACE density, shown in Figures 3 and 4 for the same combinations. However, the statistically significant regions for $\mathrm{TH}$ anomalies differ from the statistically significant TC track and ACE density anomalies over WNA (Figures 3 and 4). Nevertheless, a pattern is visible when comparing Figures 3, 4 and 6. The regions associated with positive (negative) $\mathrm{TH}$ anomalies are similar to those anomalies presented in the TC track and ACE density. This relationship of TH associated with TC activity features is stronger during La Niña + QBOW and El Niño + QBOE conditions. Figure S9 only supports the results obtained during La Niña and QBO phase combinations for the deep convection development. Negative standardized anomalies in omega (ascent movement) from $1000 \mathrm{hPa}$ to $100 \mathrm{hPa}$, whose values benefit deep convection development, dominate almost the whole NA under La Niña + QBOW (Figure S9e). However, this pattern changes for the latitudes higher than $15^{\circ} \mathrm{N}$ (Figure S9f) under La Niña + QBOE, where large-scale environments become adverse for deep convection development. The positive standardized anomalies in omega represent descent movement. 

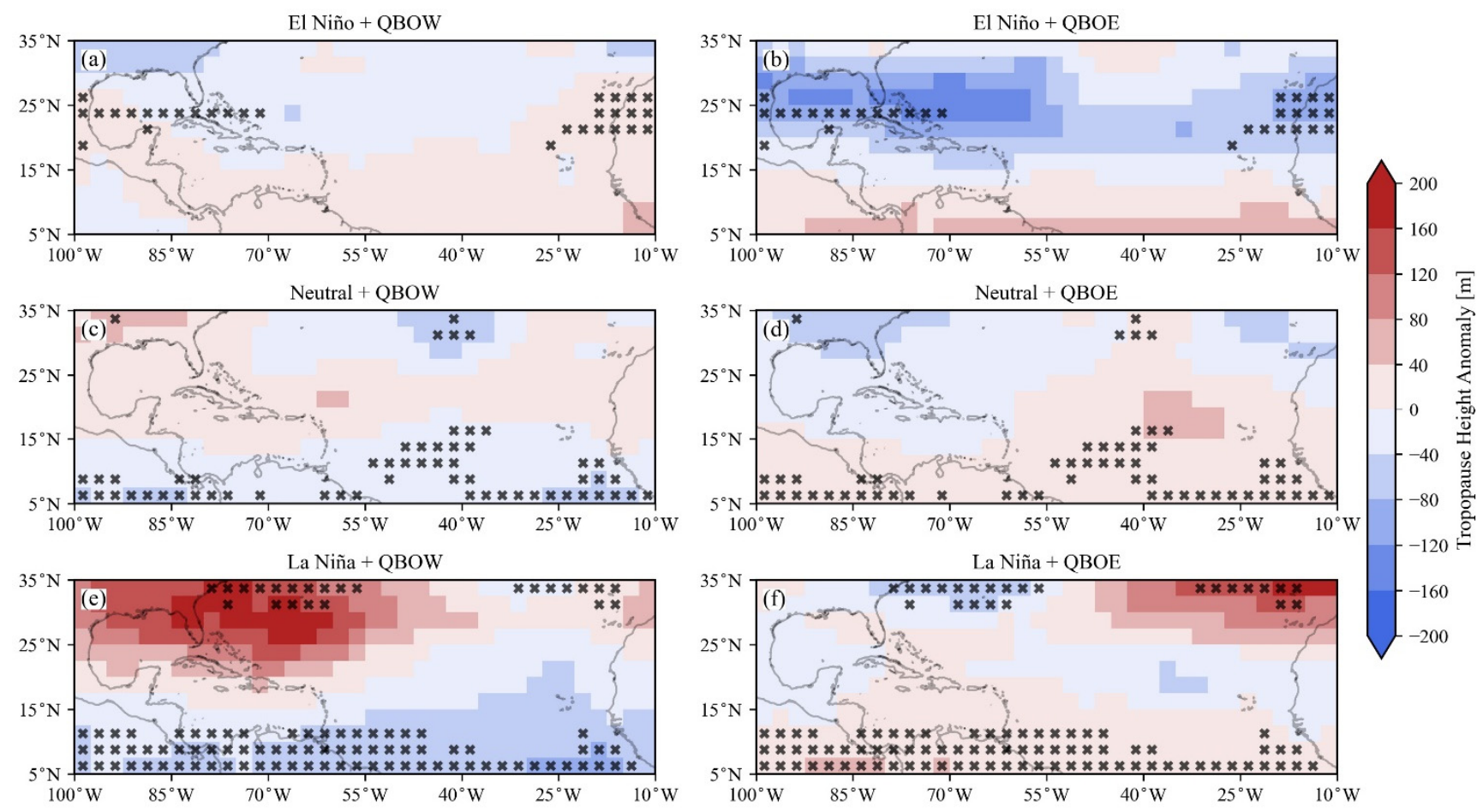

Figure 6. (a) El Niño + QBOW, (b) El Niño + QBOE, (c) Neutral + QBOW, (d) Neutral + QBOE, (e) La Niña + QBOW, and (f) La Niña + QBOE. Same as Figure 3 for the NCEP-NCAR tropopause height anomalies for the season JJASON for the years classified by ENSO and QBO phases during the 1953-2020 period. The crosses show the regions where the $p$-value of the Mann-Whitney $\mathrm{U}$ test is lower than 0.1.

To analyze QBO influence on TH at different latitudes, we construct a time series of standardized anomalies in mean TH and ACE for WNA (Figure S10a) and WMDR (Figure S10b). The Pearson (Spearman) correlation coefficient between TH and ACE anomalies is 0.44 (0.35) for WNA and 0.13 (0.18) for WMDR. The Pearson and Spearman correlation coefficients are statistically significant for WNA at a $99 \%$ significance level. Nevertheless, the correlation coefficients are not statistically significant for WMDR. The latter supports the hypothesis that QBO influences deep convection through the modulation of $\mathrm{TH}$. Therefore, our results suggest that $\mathrm{QBO}$ provides large-scale conditions that might be favorable for deep convection development, impacting TC activity over the subtropics. Nevertheless, it is necessary to also consider the ENSO signal, as their effects can enhance or suppress the modulation of $\mathrm{QBO}$ phases.

Following Collimore et al. (2003), we explored the TH and V70-V150 anomalies to show the cross-tropopause mean meridional circulation (Figure 7). Mean TH anomalies are presented using solid black lines, with their units located on the left vertical axis. V70-V150 anomalies are presented using dashed red lines with their units located on the right vertical axis for all ENSO-QBO combinations. The shaded bands indicate the corresponding estimated standard error of the mean. The sign of V70-V150 anomalies indicates the tendency in the rotation of winds at the cross-tropopause region. For instance, positive (negative) values indicate clockwise (anticlockwise) rotation in the cross-tropopause over NA. The most contrasting combinations are El Niño + QBOE (Figure 7b) and La Niña + QBOW (Figure 7e), as they depict opposite behavior not only in the TH anomalies but also in V70-V150 anomalies. El Niño + QBOE induces low TH anomalies and clockwise rotating winds in the cross-tropopause over subtropical latitudes, while La Niña + QBOW produces high $\mathrm{TH}$ anomalies and anticlockwise rotating winds at these latitudes. A schematic representation of this rotation under the two contrasting ENSO-QBO cases is provided in Figure 8. This figure resembles the schematic of the MMC induced by the QBO phases presented by Collimore et al. (2003) (see Figure 1 in [10]), who did not 
consider the ENSO phases. This MMC is such clear when the QBO phases are combined with certain ENSO phases, particularly when El Niño + QBOE and La Niña + QBOW are considered (Figure $7 b, e$ ), that the schematic represented in Figure 1 of [10] emerges. Note that the Neutral signal combined with QBO phases does not reveal the MMC due to the suppression of QBO effects by the ENSO signal (see TH spatial distributions in Figures S6 and S7). Therefore, these results support the idea that the QBO effects on deep convection and particularly on TCs should be studied in combination with ENSO, because the signal of these two oscillations can be amplified or weakened depending on the phase combinations. In this way, the effects of QBO should not be considered independently of ENSO, as previous studies have presented.
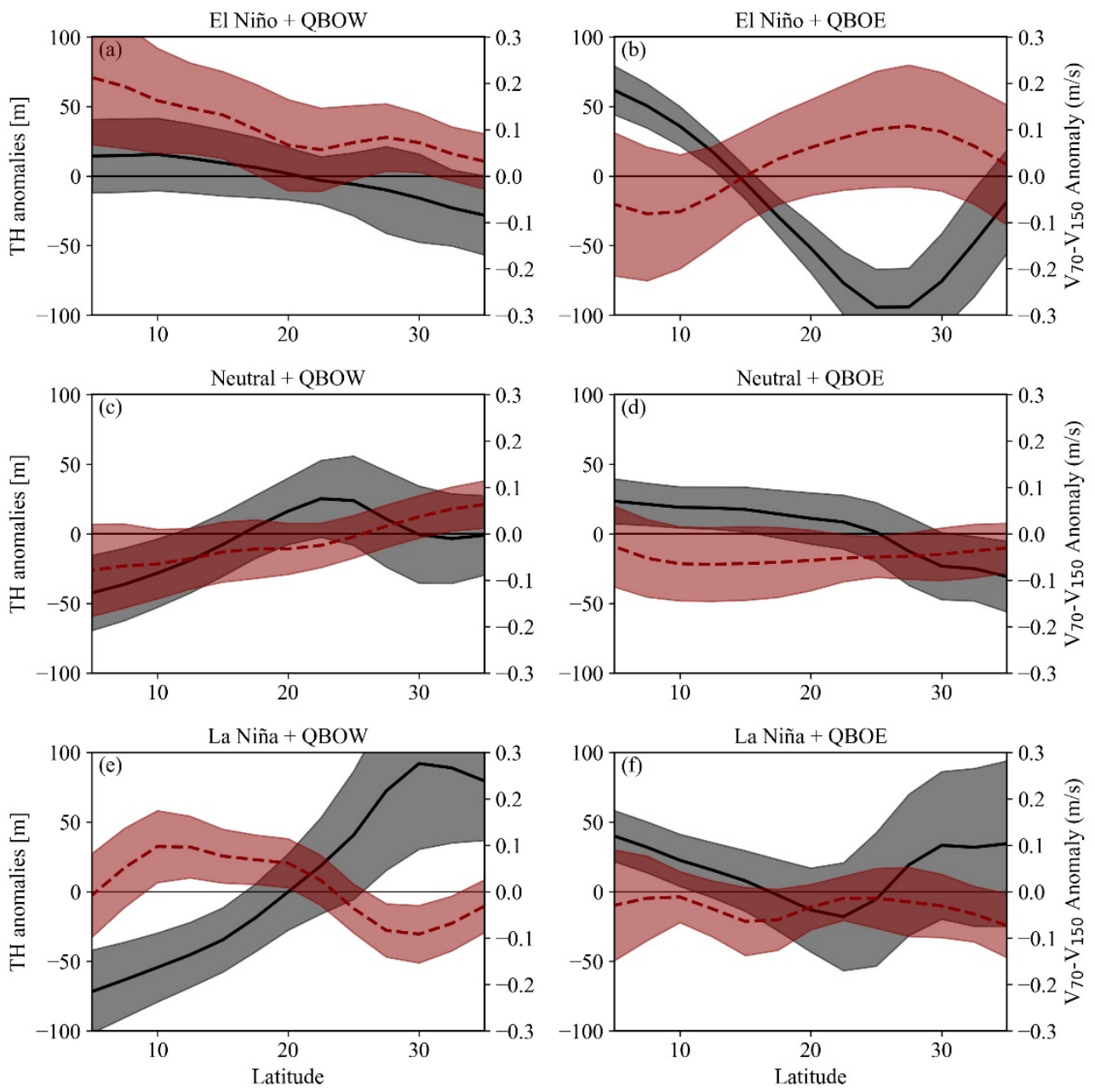

Figure 7. Mean NCEP-NCAR tropopause height anomalies (solid black line and left vertical axis) with V70-V150 anomalies (dashed red line and right vertical axis) during the season JJASON for the years classified as ENSO and QBO phases: (a) El Niño-QBOW, (b) El Niño-QBOE, (c) Neutral-QBOW, (d) Neutral-QBOE, (e) La Niña-QBOW, and (f) La Niña-QBOE during the 1953-2020 period. 

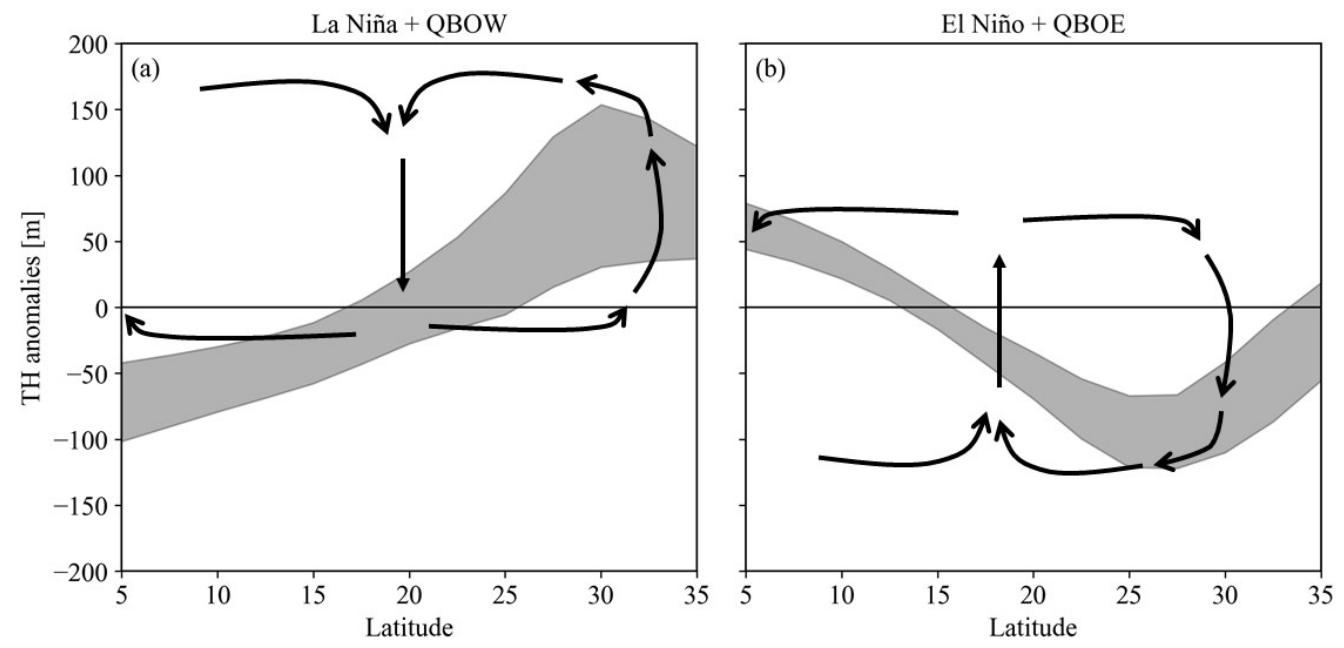

Figure 8. Schematic representation of the mean meridional circulation presented in Figure $7 \mathrm{~b}$,e with the tropopause height anomalies. The arrows indicate the meridional circulation suggested by the V70-V150 anomalies in Figure 8. (a) El Niño + QBOW, (b) El Niño + QBOE.

\section{Summary and Conclusions}

The Quasi-Biennal Oscillation (QBO) and the El Niño-Southern Oscillation (ENSO) largely modulate the zonal wind on the tropics. Gray et al. (1992) and Collimore et al. (2003) point out that QBO also impact deep convection over the tropics and subtropics. Particularly, Collimore et al. (2003) show that the Mean Meridional Circulation (MMC) can increase the tropopause height over the tropics and simultaneously decrease it over the subtropics or vice-versa, depending on the QBO phase. Interestingly, previous studies emphasized the influence of QBO on tropical cyclone (TC) activity over the North Atlantic Ocean (NA), but their approach prevents QBO phases from interacting with ENSO signals.

This study demonstrates that tropopause height is higher on average over the subtropics (defined as a region from $15^{\circ} \mathrm{N}$ to $35^{\circ} \mathrm{N}$ for this study), mainly over the Gulf of Mexico $(\mathrm{GoM})$, the Caribbean region (CR), and the Western NA (WNA) during La Niña + QBOW, which would favor deeper tropical convection over those regions. As a consequence, TC activity over those regions is not only increased in number but also enhanced in intensity. Interestingly, the TC activity in 2020 belonged to La Niña + QBOW when 12 TCs formed or intensified over GoM and the Central American coast. La Niña + QBOE is not as active as La Niña + QBOW, and especially different for WNA, where TCs are less active and intense (represented by the Accumulated Cyclonic Energy, ACE).

Although neutral ENSO combinations with QBO phases result in slightly distinct spatial patterns, TC density is higher over the Western Main Development Region (WMDR) and CR under Neutral + QBOE. However, slight differences are found in the ACE for WMDR.

Finally, variations during El Niño are observed associated with the QBO phase. During $\mathrm{El} \mathrm{Niño} \mathrm{+} \mathrm{QBOE,} \mathrm{most} \mathrm{deep} \mathrm{tropical} \mathrm{convection} \mathrm{is} \mathrm{inhibited} \mathrm{over} \mathrm{GoM,} \mathrm{CR,} \mathrm{and} \mathrm{WNA.} \mathrm{This}$ result is associated with a decrease in tropopause height $(\mathrm{TH})$ over the subtropics $\left(15^{\circ} \mathrm{N}\right.$ to $35^{\circ} \mathrm{N}$ ), and this shrink in $\mathrm{TH}$ reduces the chances of developing deep tropical convection, diminishing the TC number and ACE. Thus, the combination El Niño + QBOE has the opposite signal to La Niña + QBOW. During El Niño + QBOW, TC activity is somehow more active in the subtropics when compared to El Niño + QBOE because of the slight sinking of the tropopause. Thus, we strongly suggest that the QBO effects are through modulation in $\mathrm{TH}$, becoming more important over the subtropics. This modulation of $\mathrm{QBO}$ on $\mathrm{TH}$ is related to the changes in the cross-tropopause mean meridional circulation induced by QBO phases, which are modified by the ENSO phases. In this way, deep convection (especially TCs) modulated by QBO should be studied combined with ENSO.

Additional comparative studies using long record data at high vertical resolution are needed to fully understand to what extend QBO interacts with ENSO in the lower tropical 
stratosphere and upper tropical troposphere. These further studies are needed to explore in detail the cross-tropopause mean meridional circulation induced by QBO phases and their interactions with ENSO phases. Future work should analyze the tropical cyclone activity over the Eastern Pacific Ocean. Furthermore, future work should analyze the skill of global climate models participating in the Coupled Model Intercomparison Project v6 (CMIP6) in simulating the QBO-ENSO influence on TC activity. The latter becomes relevant for climate change scenarios or even regional climate change scenarios of TC activity, as regional models are forced with global model outputs. It would be important to determine whether these regional scenarios (e.g., Domínguez et al. (2021) [36]) can capture this QBO-ENSO influence on TCs.

Supplementary Materials: The following are available online at https://www.mdpi.com/article/ 10.3390/atmos12121588/s1, Table S1: Classification of the years from 1953 to 2020 by ENSO+QBO phases. Figure S1: Mean TCs track density anomalies during the season JJASON for the years classified as ENSO and QBO phases: (a) El Niño-QBOW, (b) El Niño-QBOE, (c) Neutral-QBOW, (d) Neutral-QBOE, (e) La Niña-QBOW, and (f) La Niña-QBOE during the 1953-2020 period. The crosses show the regions where the $p$-value of a two-sided T-test is lower than 0.1. Figure S2: Mean TCs track density anomalies for the whole domain of North Atlantic for each ENSO-QBO phase combination during the 1953-2020 period. Figure S3: Same as Figure S1, but for the Mean ACE density anomalies during the season JJASON for the years classified as ENSO and QBO phases during 1953-2020 period. The crosses show the regions where the $p$-value of a two-sided $T$-test is lower than 0.1. Figure S4: Mean SSTs and standardized anomalies of tropospheric vertical wind shear between $850 \mathrm{hPa}$ and $200 \mathrm{hPa}$ during the season JJASON for the years classified as ENSO and QBO phases during the 1953-2020 period. Figure S5: Time series of (a) the mean tropopause height (TH) in the study region for the 1953-2020 period, and (b) filtered TH after removing multidecadal variability. Figure S6: Mean tropopause height anomaly during the season JJASON for the years classified by ENSO phase: (a) El Niño, (b) Neutral, and (c) La Niña during the 1953-2020 period. Figure S7: Mean tropopause height anomaly during the season JJASON for the years classified by QBO: (a) $\mathrm{QBO}(\mathrm{W})$ and (b) $\mathrm{QBO}(\mathrm{E})$ during the 1953-2020 period. Figure S8: Same as Figure 6 for the NCEP-NCAR tropopause height anomalies for the season JJASON for the years classified by ENSO and QBO phases during the 1953-2020 period. The crosses show the regions where the $p$-value of a two-sided T-test is lower than 0.1. Figure S9: Cross-section standardized anomalies in of the pressure vertical velocity (Omega) anomalies for the season JJASON for the years classified by ENSO and QBO phases during the 1953-2020 period. Figure S10: Time series of standardized anomalies for mean tropopause height (black) and ACE (red) for the boxes in (a) the WNA and (b) the WMDR during the 1953-2020 period.

Author Contributions: Conceptualization, A.J., C.D., G.R. and A.I.Q.; methodology, A.J.; validation, A.J., C.D., G.R. and A.I.Q.; formal analysis, A.J., C.D.; writing-original draft preparation, A.J., C.D., G.R. and A.I.Q.; writing—review and editing, A.J., C.D., G.R. and A.I.Q.; visualization, A.J.; supervision, G.R. and A.I.Q.; funding acquisition, C.D. All authors have read and agreed to the published version of the manuscript.

Funding: This study was financially supported by UNAM-PAPIIT under the grant IA100620 “Eventos extremos de precipitación producidos por fenómenos tropicales".

Institutional Review Board Statement: Not applicable.

Informed Consent Statement: Not applicable.

Data Availability Statement: The HURDAT data can be found at https://www.nhc.noaa.gov/ data / (accessed on 25 November 2021). The University of Berlin's QBO dataset is available at http: //www.geo.fu-berlin.de/en/met/ag/strat/produkte/qbo/index.html (accessed on 25 November 2021). NCEP-NCAR reanalysis can be found at https://psl.noaa.gov/data/gridded/data.ncep. reanalysis.tropopause.html (accessed on 25 November 2021). The ONI index can be obtained at https://origin.cpc.ncep.noaa.gov/products/analysis_monitoring/ensostuff/ONI_v5.php (accessed on 25 November 2021).

Acknowledgments: The authors are grateful to the academic editors for their support and two anonymous reviewers who provided insightful suggestions that improved this manuscript. We 
acknowledge The University of Berlin for providing the QBO dataset, the NHC for providing the HURDAT data, and the NCEP Reanalysis data provided by the NOAA/OAR/ESRL PSL, Boulder, Colorado, USA, from their Web site at https://psl.noaa.gov/data/gridded/data.ncep.reanalysis. tropopause.html (accessed on 25 November 2021).

Conflicts of Interest: The authors declare no conflict of interest.

\section{References}

1. Baldwin, M.P.; Gray, L.J.; Dunkerton, T.J.; Hamilton, K.; Haynes, P.H.; Randel, W.J.; Holton, J.R.; Alexander, M.J.; Hirota, I.; Horinouchi, T.; et al. The quasi-biennial oscillation. Rev. Geophys. 2001, 39, 179-229. [CrossRef]

2. Naujokat, B. An update of the observed quasi-biennial oscillation of the stratospheric winds over the tropics. J. Atmos. Sci. 1986, 43, 1873-1877. [CrossRef]

3. Baldwin, M.P.; Gray, L.J. Tropical stratospheric zonal winds in ECMWF ERA-40 reanalysis, rocketsonde data, and rawinsonde data. Geophys. Res. Lett. 2005, 32, L09806. [CrossRef]

4. Holton, J.R.; Haynes, P.H.; McIntyre, M.E.; Douglass, A.R.; Rood, R.B.; Pfister, L. Stratosphere-troposphere exchange. Rev. Geophys. 1995, 33, 403-439. [CrossRef]

5. Haynes, P.; Hitchcock, P.; Hitchman, M.; Yoden, S.; Hendon, H.; Kiladis, G.; Kodera, K.; Simpson, I. The influence of the stratosphere on the tropical troposphere. J. Meteorol. Soc. Jpn. Ser. II 2021, 99, 803-845. [CrossRef]

6. Martin, Z.; Son, S.-W.; Butler, A.; Hendon, H.; Kim, H.; Sobel, A.; Yoden, S.; Zhang, C. The influence of the quasi-biennial oscillation on the madden-julian oscillation. Nat. Rev. Earth Environ. 2021, 2, 477-489. [CrossRef]

7. Hansen, F.; Matthes, K.; Wahl, S. Tropospheric QBO-ENSO interactions and differences between the atlantic and pacific. J. Clim. 2016, 29, 1353-1368. [CrossRef]

8. Taguchi, M. Observed connection of the stratospheric quasi-biennial oscillation with el niño-southern oscillation in radiosonde data. J. Geophys. Res. Atmos. 2010, 115, D18120. [CrossRef]

9. Gray, W.M.; Sheaffer, J.D.; Knaff, J.A. Influence of the stratospheric QBO on ENSO variability. J. Meteorol. Soc. Jpn. Ser. II 1992, 70, 975-995. [CrossRef]

10. Collimore, C.C.; Martin, D.W.; Hitchman, M.H.; Huesmann, A.; Waliser, D.E. On The relationship between the QBO and tropical deep convection. J. Clin. 2003, 16, 2552-2568. [CrossRef]

11. Hitchman, M.H.; Yoden, S.; Haynes, P.H.; Kumar, V.; Tegtmeier, S. An observational history of the direct influence of the stratospheric quasi-biennial oscillation on the tropical and subtropical upper troposphere and lower stratosphere. J. Meteorol. Soc. Jpn. Ser. II 2021, 99, 239-267. [CrossRef]

12. Gray, W.M. Atlantic seasonal hurricane frequency. Part I: El niño and $30 \mathrm{Mb}$ quasi-biennial oscillation influences. Mon. Weather. Rev. 1984, 112, 1649-1668. [CrossRef]

13. Landsea, C.W.; Gray, W.M. The strong association between western sahelian monsoon rainfall and intense atlantic hurricanes. J. Clim. 1992, 5, 435-453. [CrossRef]

14. Klotzbach, P.J.; Gray, W.M. Updated 6-11-month prediction of atlantic basin seasonal hurricane activity. Weather Forecast. 2004, 19, 917-934. [CrossRef]

15. Fink, A.H.; Schrage, J.M.; Kotthaus, S. On the potential causes of the nonstationary correlations between west african precipitation and atlantic hurricane activity. J. Clim. 2010, 23, 5437-5456. [CrossRef]

16. Camargo, S.J.; Sobel, A.H. Revisiting the influence of the quasi-biennial oscillation on tropical cyclone activity. J. Clim. 2010, 23, 5810-5825. [CrossRef]

17. Camargo, S.J.; Emanuel, K.A.; Sobel, A.H. Use of a genesis potential index to diagnose ENSO effects on tropical cyclone genesis. J. Clim. 2007, 20, 4819-4834. [CrossRef]

18. Shapiro, L.J.; Goldenberg, S.B. Atlantic sea surface temperatures and tropical cyclone formation. J. Clim. 1998, 11, 578-590. [CrossRef]

19. Ho, C.-H.; Kim, H.-S.; Jeong, J.-H.; Son, S.-W. Influence of stratospheric quasi-biennial oscillation on tropical cyclone tracks in the western north pacific. Geophys. Res. Lett. 2009, 36, L06702. [CrossRef]

20. Huangfu, J.; Tang, Y.; Ma, T.; Chen, W.; Wang, L. Influence of the QBO on tropical convection and its impact on tropical cyclone activity over the western north pacific. Clim. Dyn. 2021, 57, 657-669. [CrossRef]

21. Dominguez, C.; Magaña, V. The role of tropical cyclones in precipitation over the tropical and subtropical North America. Front. Earth Sci. 2018, 6, 19. [CrossRef]

22. Dominguez, C.; Jaramillo, A.; Cuéllar, P. Are the socioeconomic impacts associated with tropical cyclones in mexico exacerbated by local vulnerability and ENSO conditions? Int. J. Climatol. 2021, 41, E3307-E3324. [CrossRef]

23. Kalnay, E.; Kanamitsu, M.; Kistler, R.; Collins, W.; Deaven, D.; Gandin, L.; Iredell, M.; Saha, S.; White, G.; Woollen, J.; et al. The NCEP/NCAR 40-year reanalysis project. Bull. Am. Meteorol. Soc. 1996, 77, 437-472. [CrossRef]

24. Huang, B.; L'Heureux, M.; Hu, Z.-Z.; Zhang, H.-M. Ranking the strongest ENSO events while incorporating SST uncertainty: ENSO RANKING. Geophys. Res. Lett. 2016, 43, 9165-9172. [CrossRef]

25. Glantz, M.H.; Ramirez, I.J. Reviewing the oceanic niño index (ONI) to enhance societal readiness for el niño's impacts. Int. J. Disaster Risk Sci. 2020, 11, 394-403. [CrossRef] 
26. Landsea, C.W.; Franklin, J.L. Atlantic hurricane database uncertainty and presentation of a new database format. Mon. Weather Rev. 2013, 141, 3576-3592. [CrossRef]

27. Vecchi, G.A.; Knutson, T.R. On estimates of historical north atlantic tropical cyclone activity*. J. Clim. 2008, 21, 3580-3600. [CrossRef]

28. Landsea, C.W.; Vecchi, G.A.; Bengtsson, L.; Knutson, T.R. Impact of duration thresholds on atlantic tropical cyclone counts. J. Clim. 2010, 23, 2508-2519. [CrossRef]

29. Bell, G.D.; Halpert, M.S.; Schnell, R.C.; Higgins, R.W.; Lawrimore, J.; Kousky, V.E.; Tinker, R.; Thiaw, W.; Chelliah, M.; Artusa, A. Climate assessment for 1999. Bull. Am. Meteorol. Soc. 2000, 81, S1-S48. [CrossRef]

30. Pawson, S.; Fiorino, M. A comparison of reanalyses in the tropical stratosphere. Part 3: Inclusion of the pre-satellite data era. Clim. Dyn. 1999, 15, 241-250. [CrossRef]

31. Randel, W.J.; Wu, F.; Gaffen, D.J. Interannual variability of the tropical tropopause derived from radiosonde data and NCEP reanalyses. J. Geophys. Res. 2000, 105, 15509-15523. [CrossRef]

32. Sun, Y.; Li, L.Z.X.; Ramstein, G.; Zhou, T.; Tan, N.; Kageyama, M.; Wang, S. Regional meridional cells governing the interannual variability of the hadley circulation in boreal winter. Clim. Dyn. 2019, 52, 831-853. [CrossRef]

33. Liess, S.; Geller, M.A. On the relationship between QBO and distribution of tropical deep convection: Relationship between QBO and convection. J. Geophys. Res. 2012, 117, D03108. [CrossRef]

34. Plumb, R.A.; Bell, R.C. A model of the quasi-biennial oscillation on an equatorial beta-plane. Q. J. R. Met. Soc. 1982, 108, 335-352. [CrossRef]

35. Huesmann, A.S.; Hitchman, M.H. The stratospheric quasi-biennial oscillation in the NCEP reanalyses: Climatological structures. J. Geophys. Res. 2001, 106, 11859-11874. [CrossRef]

36. Dominguez, C.; Done, J.M.; Bruyère, C.L. Future Changes in Tropical Cyclone and Easterly Wave Characteristics over Tropical North America. Oceans 2021, 2, 429-447. [CrossRef] 